\title{
Keefektifan Model Pembelajaran Make A Match terhadap Hasil Belajar Ilmu Pengetahuan Alam
}

\author{
Aristianto* \\ Program Studi Pendidikan Guru Sekolah Dasar
}

\section{A R T I C LE I N F O \\ Article history: \\ Received 18 Desember 2017 \\ Received in revised form 30 Desember 2017 Accepted 15 Januari 2018 \\ Available online 20 \\ Februari 2018}

\section{Kata Kunci:}

Model Make a Match, Hasil Belajar, Ilmu Pengetahuan Alam

Keywords:

Make a Match Model, Learning Outcomes, Natural Sciences

\begin{abstract}
A B S T RAK
Keefektifan Model Pembelajaranan Make a Match Terhadap Hasil Belajar Ilmu Pengetahuan Alam Siswa Kelas V SD Negeri Wonosri 03". Tujuan yang hendak dicapai dalam penelitian ini adalah Untuk mengetahui apakah model Make a Match efektif terhadap hasil belajar Ilmu Pengetahuan Alam siswa kelas V SD Negeri Wonosri 03. Metode penelitian kuantitatif dalam bentuk Pre-Experimental Design dengan teknik One-Group Pretest-Posttest Design. Populasi penelitian adalah seluruh siswa kelas $V$ SD Negeri Wonosri 03 Tahun Pelajaran 2018/2019. Sampel yang diambil adalah 30 siswa kelas $V$ dengan menggunakan tekni Sampling Jenuh. Data penelitian ini diperoleh melalui instrumen penelitian pretest, posttest, dokumentasi dan wawancara. Setelah dilakukan pengujian hipotesis dengan analisis hasil belajar siswa materi panas dan perpindahannya ranah kognitif diperoleh nilai rata-rata kelas untuk pretest sebesar 58,8 dan posttest sebesar 74 dengan $\mathrm{n}=30$ jadi $\mathrm{db}=\mathrm{N}-1$ yang diperoleh $\mathrm{t}_{\text {hitung }}=16,078$ dengan taraf signifikan $5 \%$ didapat nilai $t_{\text {tabel }}=2,045$. Karena $t$ hitung $>t$ tabel yaitu $16,078>2,028$ maka $H_{0}$ ditolak dan $H_{a}$ diterima. Sehingga dapat dikatakan bahwa model Make a Match berpengaruh terhadap Hasil Belajar siswa materi panas dan perpindahannya kelas V SD Negeri Wonosari 03 Kabupaten Batang.
\end{abstract}

A B S T R A C T

The Effectiveness of the Learning Model Make a Match Against Natural Science Students in V-Grade Wonosri Elementary School 03". The aim to be achieved in this study is to find out whether the Make a Match model is effective against the learning outcomes of Natural Sciences in fifth grade students of SD Negeri Wonosri 03. Quantitative research methods in the form of Pre-Experimental Design with One-Group Pretest-Posttest Design techniques. The study population was all fifth grade students of Wonosri State Elementary School 03 Academic Year 2018/2019. The samples taken were 30 grade $\mathrm{V}$ students using Saturated sampling techniques. The data of this study were obtained through pretest, posttest, documentation and interview research instruments. After testing the hypothesis by analyzing the learning outcomes of hot material students and the transfer of cognitive domains obtained the value of the average class for the pretest of 58.8 and posttest of 74 with $n=30$ so $\mathrm{db}=\mathrm{N}-1$ obtained tcount $=16,078$ with a significant level of $5 \%$ obtained value ttable $=2.045$. Because $t$ count $>\mathrm{t}$ table that is $16,078>2,028$ then $\mathrm{HO}$ is rejected and $\mathrm{Ha}$ is accepted. So that it can be said that the Make a Match model influences the Learning Outcomes of hot material students and their displacement in class V of SD Negeri Wonosari 03 Batang Regency. 


\section{Pendahuluan}

Ilmu Pengetahuan Alam (IPA) adalah ilmu yang mempelajari tentang kejadian, proses, ataupun gejala alam yang disusun secara sistematis berdasarkan pada hasil percobaan dan pengamatan yang dilakukan oleh manusia. Hal ini dikemukakan oleh Powler (dalam Samatowa, 2010: 3) bahwa IPA merupakan ilmu yang berhubungan dengan gejala-gejala alam dan kebendaan yang sistematis yang tersusun secara teratur, berlaku umum yang berupa kumpulan dari hasil observasi dan eksperimen.

Berdasarkan hasil wawancara yang telah dilakukan pada guru kelas V tentang pembelajaran Ilmu Pengetahuan Alam materi yang sudah dipelajari siswa menunjukan hasil pembelajaran siswa belum maksimal. Hal ini dapat dibuktikan dari perolehan nilai ulangan harian sebanyak 7 siswa yang tuntas dan 23 siswa yang belum tuntas dalam pembelajaran Ilmu Pengetahuan Alam, bahwa siswa yang nilainya belum mencapai KKM yang ditetapakan untuk mata pelajaran Ilmu Pengetahuan Alam di SD Negeri Wonosari 03 yaitu 70.

Siswa masih mengalami kesulitan pada mata pelajaran Ilmu Pengetahuan Alam. Hal itu disebabkan cara mengajar guru yang masih menngunakan metode ceramah, Alasanya siswa kurang aktif dan merasa bosan dalam proses pembelajaran yang berlangsung di dalam kelas karena proses pembelajaran yang kurang bervaraisi dan kurang efektif. Guru menjadi salah satu faktor penentu dalam keberhasilan proses pembelajaran, guru seharusnya dapat menyajikan pembelajaran yang menarik dengan suasana yang menyenangkan. Sehingga guru harus merancang suatu pembelajaran dengan baik untuk menunjang keberhasilan suatu proses pembelajaran.

Pendidikan nasional adalah pendidikan yang berdasarkan Pancasila dan Undang-Undang Dasar Negara Republik Indonesia Tahun 1945 yang berakar pada nilai-nilai agama, kebudayaan nasional Indonesia, dan tanggap terhadap tuntutan perubahan zaman. Tujuan pendidikan nasional sebagaimana tercantum di dalam UU No. 20 Tahun 2003 Bab II Pasal 3 adalah usaha sadar dan terencana untuk mewujudkan suasana belajar dan proses pembelajaran agar peserta didik secara aktif mengembangkan potensi dirinya untuk memiliki kekuatan spiritual keagamaan, pengendalian diri, keperibadian, kecerdasan, akhlak mulia, serta keterampilan yang diperlukan dirinya, masyarakat, bangsa dan negara.

Berdasarkan studi awal dapat disimpulkan bahwa selama proses pembelajaran, guru belum menggunakan model dan metode pembelajaran yang tepat dan guru belum mencoba hal baru dalam proses pembelajaran karana oleh karena itu sebagian besar siswa belum mampu mencapai kompetensi individual yang diperlukan untuk mengikuti pelajaran lanjutan. Rendahnya ketuntasan belajar siswa ini disebabkan oleh rendahnya hasil belajar siswa mengenai materi panas dan perpindahannya yang diajarkan oleh guru. Dalam proses pembelajaran kurangnya pemanfaatan model pembelajaran sehingga hasil belajar siswa kurang maksimal. Guru masih cenderung menggunakan model ceramah dalam penyampaian materi, sehingga pembelajaran masih berpusat pada guru. Oleh karena itu, suatu model yang bervariatif perlu diterapkan dalam proses pembelajaran.

Terkait belum optimalnya hasil belajar Ilmu Pengetahuan Alam siswa kelas V SD Negeri Wonosri 03 maka dalam penelitian akan menerapkan model Make a Match sebagai salah satu alternatif pembelajaran yang bermakna pada pembelajaran aktif, kreatif, efektif, dan menyenangkan. Model Make a Match merupakan refleksi pentingnya guru dalam mengelola suatu proses pembelajaran yang nyaman sehingga siswa menjadi lebih antusias dalam proses pembelajaran.

Menurut Slameto (2010:2) belajar adalah suatu proses usaha yang dilakukan seseorang untuk memperoleh suatu perubahan tingkah laku yang baru secara keseluruhan, sebagai hasil pengalamannya sendiri dalam interaksi dengan lingkungannya. Jadi belajar adalah perubahan tingkah laku yang terjadi karena adanya respon dari luar sebagai usaha untuk memperoleh motivasi dan kepandaian yang sifatnya progresif sebagai hasil pengalamannya sendiri.

Menurut Slameto (2013: 16) hasil belajar merupakan hal yang dapat dipandang dari dua sisi yaitu sisi siswa dan dari sisi guru.Dari sisi siswa, hasil belajar merupakan tingkat perkembangan mental yang lebih baik bila dibandingkan pada saat sebelum belajar.Tingkat perkembangan mental tersebut terwujud pada jenis-jenis ranah kognitif, afektif dan psikomotor.

Berdasarkan penjelasan diatas dapat disimpulkan bahwa hasil belajar adalah bila seseorang telah belajar akan terjadi perubahan tingkah laku pada orang tersebut, misalnya dari tidak tahu menjadi tahu, dan dari tidak mengerti menjadi mengerti.

Ilmu Pengetahuan Alam merupkan Peristiwa alam dimana kejadian alam yang benar-benar terjadi disebabkan oleh dua faktor aktivitas yaitu peristiwa alam/bencana alam yang dapat ditimbulkan atau disebabkan oleh perilaku manuisa, seperti: banjir, tanah longsor, kebakaran hutan, dan persitiwa alam/bencana alam yang terjadi secara alamiah, seperti: gunung meletus, gempa bumi, tsunami.

Menurut Prabandari (2007:109) peristiwa alam adalah segala kejadian yang timbul akibat kegiatan yang dilakukan di alam. Peristiwa alam biasanya ditandai dengan adanya gelaja alam. Gejala alam yang 
muncul sehingga menjadi sebuah peristiwa alam yang sifatnya merugikan kehidupan manusia disebut bencana alam. Model pembelajaran merupakan landasan praktik pembelajaran hasil penurunan teori psikologi pendidikan dan teori belajar yang dirancang berdasarkan analisis terhadap implementasi kurikulum dan implikasinya pada tingkat operasional di kelas. Model Make a Match adalah siswa diminta mencari pasangan kartu yang merupakan jawaban atau pertanyaan materi tertentu dalam pembelajaran. Salah satu keunggulan teknik ini adalah siswa mencari pasangan sambil belajar mengenai suatu konsep atau topik dalam suasana yng menyenangkan. Teknik ini bisa digunakan dalam semua mata pelajaran dan untuk semua tingkatan usia ( Isjoni, 2010:78)

\section{Metode}

Desain penelitian dirancang untuk menjawab pertanyaan atau mengetes hipotesis penelitian.Penelitian ini menggunakan Pre Eksperimental Designs bentuk One-Group Pretest-Posttest Design. Pada desain ini terdapat pretest, sebelum diberi perlakuan. Dengan demikian hasil perlakuan dapat diketahui lebih akurat, karena dapat membandingkan dengan keadaan sebelum diberi perlakuan (Sugiyono,2014:74). Adapun desain penelitian One Group Pretest-Posttest dapat digambarkan sebagai berikut:

Tabel 1. Desain/rancangan penelitian

\begin{tabular}{ccc}
\hline Pretest & Perlakuan & Postest \\
$0_{1}$ & $\mathrm{X}$ & $0_{2}$ \\
\hline
\end{tabular}

Penelitian ini teknik non-tes digunakakan untuk mengetahui data yang tidak secara langsung.Teknik nontes yang digunakan dalam penelitian ini adalah dokumentasi. Dokumentasi dalam penelitian ini untuk mencari data mengenai hal-hal atau variabel yang berupa catatan, transkip, buku dan sebagainya. Jadi metode dokumentasi dalam penelitian ini digunakan untuk mendapatkan dokumen tentang data penelitian yang dibutuhkan dalam penelitian. Dokumentasi juga dapat digunakan untuk bukti konkret saat melakukan penelitian. 1) Dokumentasi, dokumentasi bertujuan untuk menangkap fakta pada saat pelaksanaan penelitian berupa data-data sekunder (daftar nama siswa serta hasil nilai pretest dan posttest) dan dokumentasi pelaksanaan pembelajaran saat penelitian). 2) Wawancara, wawancara digunakan untuk menemukan permasalahan yang harus diteliti, dan juga apabila peneliti ingin mengetahui hal-hal dari responden yang lebih mendalam dan jumlah respondennya sedikit/kecil. Peneliti sudah melakukan wawancara dengan menggunakan pedoman wawancara yang sudah dibuat sebelumnya terhadap guru kelas V SDN Wonosari 03 guna mendapatkan informasi awal tentang berbagai permasalah yang ada pada pembelajaran khusunya mata pelajaran Ilmu Pengetahuan Alam.

Tes yang dilakukan dalam penelitian ini dibagi menjadi dua yaitu pretest dan posttest. Pretest adalah tes yang dilakukan sebelum dilaksanakan proses pembelajaran, sedangkan posttest adalah tes yang dilakukan setelah proses pembelajaran. Menggunakan metode tes ini dapat diperoleh data hasil belajar siswa yang diambil dari hasil evaluasi siswa. Adapun materi tes dalam penelitian ini adalah materi yang disesuaikan dengan kompetensi dasar pada Kurikulum 2013. pada mata pelajaran llmu Pengetahuan Alam kelas V. Bentuk soal yang digunakan adalah pilihan ganda.

\section{Hasil dan Pembahasan}

Berdasarkan data hasil pretest dan posttest siswa kelas V SD Negeri Wonosari 03 Kabupaten Batang tahun ajaran 2018/2019 sebagai subjek penelitian maka dilakukan uji hipotesis, untuk menguji perbedaan rata-rata hasil pretest dan posttest digunakan uji t. Hipotesis yang diuji adalah sebagai berikut: $\mathrm{H}_{\mathrm{a}}=\mathrm{t}_{\text {hitung }} \mathrm{t}_{\text {tabel }}$ model pembelajaran Make a Match berpengaruh terhadap hasil belajar Ilmu pengetahuan alam kelas kelas V SD Negeri Wonosari 03 Kabupaten Batang. $H_{0}=t_{\text {hitung }}<t_{\text {tabel }}$ model pembelajaran Make a Match tidak berpengaruh terhadap hasil belajar Ilmu pengetahuan alam kelas V SD Negeri Wonosari 03 Kabupaten Batang. 
Tabel 2. Hasil Perhitungan Uji t

\begin{tabular}{llllllll}
\hline Subjek & $\begin{array}{l}\text { Hasil } \\
\text { Belajar }\end{array}$ & $\begin{array}{l}\text { Rata- } \\
\text { rata }\end{array}$ & $\mathrm{N}$ & $\mathrm{Md}$ & $\sum \mathrm{x}^{2} \mathrm{~d}$ & $\mathrm{t}_{\text {hitung }}$ & $\mathrm{t}_{\text {tabel }}$ \\
\hline $\begin{array}{l}\text { kelas V SD Negeri } \\
\begin{array}{l}\text { Wonosari } 03 \\
\text { Kabupaten Batang }\end{array}\end{array}$ & Pretest & 58,8 & 30 & 15,167 & 774,167 & 16,078 & 2,045 \\
& Postest & 74 & & & & & \\
\hline
\end{tabular}

(Sumber: Data Hasil Penelitian 2019)

Data hasil pretest dan posttest kemudian dianalisis menggunakan uji t. dapat dilihat dari Tabel 4.9 bahwa rata-rata siswa pada kondisi awal sebelum perlakuan dengan menggunakan model pembelajaran Make a Match sebesar 58,8, sedangkan rata-rata siswa sesudah diberi perlakuan dengan menggunakan model pembelajaran Make a Match sebesar 74. Dari data analisis uji t diperoleh $\mathrm{t}_{\text {hitung }}=16,078$ selanjutnya dibandingkan dengan $\mathrm{t}_{\text {tabel }}=2,045$ dengan $\mathrm{db}=30-1$ pada taraf signifikan $\alpha=5 \%$. Hasil ini menunjukkan bahwa $t_{\text {hitung }}>\mathrm{t}_{\text {tabel }}$ yaitu $12,890>2,0639$ maka $\mathrm{H}_{0}$ ditolak dan $\mathrm{H}_{\mathrm{a}}$ diterima. Sehingga dapat dikatakan bahwa model pembelajaran Make a Match berpengaruh terhadap hasil belajar siswa pada mata pelajaran llmu Pengetahuan Alam kelas V SD Negeri Wonosari 03 Kabupaten Batang

Penelitian ini dilaksanakan pada semester genap tahun ajaran 2018/2019. Penelitian ini dilaksanakan di k V dengan jumlah 30 siswa. Sebelum melaksanakan penelitian, peneliti melaksanakan wawancara dengan guru kelas $\mathrm{V}$ untuk mengetahui permasalahan yang ada di kelas dan diperoleh informasi bahwa dalam proses pembelajaran llmu Pengetahuan Alam di kelas V serta guru masih menggunakan model ceramah. Sehingga pembelajaran yang dilakukan terkesan membuat siswa cepat merasa bosan. Akibat yang muncul karena permasalahan tersebut terlihat pada hasil nilai Ulangan Harian yang memiliki nilai rata-rata rendah dan belum mencapai Kriteria Ketuntasan Minimal (KKM) yang sudah ditentukan yaitu 70. Dari jumlah 30 siswa, 7 siswa tuntas dan 23 siswa belum tuntas.

Peneliti mempersiapkan rencana pelaksanaan pembelajaran yang akan dilaksanakan adalah $3 \mathrm{kali}$ pertemuan. Rencana Pelaksanaan Pembelajaran (RPP) dilaksanakan dengan menggunakan model pembelajaran Make a Match. Pada hari pertama peneliti terlebih dahulu saling memperkenalkan dan kemudian membagikan soal pilihan ganda sebagai pretest kepada siswa untuk dikerjakan.

Model pembelajaran Make a Match merupakan pembelajaran yang memberikan kesempatan kepada siswa untuk berlatih bekerja sama dengan pasangannya. Berdasarkan situasi nyata, siswa didorong untuk berlatih secara berpasangan dengan temannya secara bergantian dengan menggunakan media kartu soal dan kartu jawaban yang telah disediakan oleh peneliti pada masing-masing kelompok, sehingga siswa lebih mudah untuk memahami tentang materi panas dan perpindahannya. Proses pembelajaran menggunakan model pembelajaran Make a Match yang dilakukan peneliti sesuai dengan langkah-langkah yang telah diuraikan di atas. Langkah petama yaitu memilih satu keterampilan yang akan dipelajari siswa. Disini keterampilan yang dipelaajari yaitu tentang materi panas dan perpindahannya. Langkah kedua guru menyiapkan beberapa kartu yang berisi beberapa konsep atau topik yang d pelajari siswa untuk sesi review, sebaliknya satu bagian kartu yang berisi soal dan bagian kartu lainya berisi jawaban. Langkah ketiga setiap siswa yang mendapatkan kartu yang berisi soal/ jawaban mendapat satu anank satu buah kartu. Langkah keempat tiap siswa yang telah mendapatkan satu buah kartu memkirkan jawaban/soal dari kartu yang dipegang,untuk nanti mencari pasangan kartu yang di dapatkan. Langkah kelima setiap siswa harus mencari pasangan dari kartu yang di pegang untuk mencari kartua yang cocok dengan kartunya (soal jawaban). Langkah keenam setiap siswa yang dapat mencocokan kartunya sebelum batas waktu diberi, diharapkan untuk siswa maju kedepan untuk menyampaikan pasangan dari soal dan jawaban yang telah di dapat. Langkah ketujuh guru memberikan poin atau reword kepada siswa yang cepat mencocokan soal dan jawaban. Langkah kedelapan setelah satu babak selesai, guru mengkocok kartu kembali agar tiap siswa mendapat kartu yang berbeda dari sebelumnya. Demikian seterusnya.

Selesai memberikan materi dari pertemuan pertama dan kedua pada akhir pertemun pembelajaran siswa akan diberi soal posttest sebagai alat evaluasi sehingga akan diketahui apakah model pembelajaran Make a Match akan meningkatkan hasil belajar siswa pada mata pelajaran llmu Pengetahuan Alam kelas V di SD Negeri Wonosari 03 Kabupaten Batang.

Berdasarkan perhitungan nilai pretest yang dilakukan diperoleh kesimpulan bahwa kelas V SD Negeri Wonosari 03 Kabupaten Batang berdistribusi normal karena nilai $L_{0}<L_{\text {tabel }}$ yaitu $0,148<0,161$ dengan $n=30$ dan taraf nyata $\alpha=0,05$. Pada tahap akhir berikutnya dilakukan kembali uji normalitas dengan menggunakan nilai posttest. Berdasarkan perhitungan diperoleh $\mathrm{L}_{0}=0,137$ dengan $\mathrm{n}=30$ dan 
taraf nyata $\alpha=0,05$, dari daftar nilai kritis $L$ didapat $L_{\text {tabel }}=0,161$. Karena $L_{0}<L_{\text {tabel }}$ yaitu $0,137<0,161$, maka $\mathrm{H}_{0}$ diterima sehingga dapat disimpulkan bahwa sampel berasal dari populasi berdistribusi normal.

Selain nilai pretest dan posttest yang nantinya digunakan sebagai nilai aspek kognitif, dari pertemuan ke-1 sampai dengan pertemuan ke-3. Setelah dilakukan pengujian hipotesis dengan analisis hasil belajar siswa materi panas dan perpindahannya ranah kognitif diperoleh nilai rata-rata kelas untuk pretest sebesar 58,8 dan posttest sebesar 74 dengan $n=30$ jadi $d b=N-1$ yang diperoleh $t_{\text {hitung }}=16,078$ dengan taraf signifikan 5\% didapat nilai $t_{\text {tabel }}=2,045$. Karena $t_{\text {hitung }}>t$ tabel yaitu 16,078 $>2,028$ maka $\mathrm{H}_{0}$ ditolak dan $\mathrm{H}_{\mathrm{a}}$ diterima. Sehingga dapat dikatakan bahwa model Make a Match berpengaruh terhadap Hasil Belajar siswa materi panas dan perpindahannya kelas V SD Negeri Wonosari 03 Kabupaten Batang.

Suyono (2016: 105) mengatakan Teori belajar Konstruktivisme melandasi pemikirannya bahwa pengetahuan bukanlah sesuatu yang given dari alam karena hasil kontak manusia dengan alam, tetapi pengetahuan merupakan hasil konstruksi (bentukan) aktif manusia itu sendiri.

Dengan demikian tujuan peneliti telah tercapai yaitu peneliti telah membuktikan bahwa model pembelajaran Make a Match berpengaruh terhadap hasil belajar pada mata pelajaran llmu Pengetahuan Alam kelas V SD Negeri Wonosari 03 Kabupaten Batang.

Berdasarkan hasil Penelitian yang mengkaji tentang strategi pembelajaran model Make a Match, bahwa penelitian yang telah dilaksanakan menunjukkan bahwa strategi Make a Match merupakan strategi pembelajaran yang dapat meningkatkan hasil belajar siswa. Berikut penelitian-penelitian yang mengkaji strategi Make a Match. Sebuah penelitian yang dilakukan oleh Nurlia Astika. 2012. Dengan judul Keefektifan Model Pembelajaran Kooperatif Tipe Make a Match Terhadap Hasil Belajar Siswa. Berdasarkan pembahasan di atas, dapat diambil kesimpulan bahwa: 1. Model pembelajaran kooperatif tipe make a-match lebih efektif untuk meningkatkan hasil belajar siswa. 2. Berdasarkan data yang diperoleh, terlihat bahwa untuk aspek pengetahuan (C1) secara umum prosentase Keefektifan lebih didominasi oleh kelas kontrol yaitu 74\% sedangkan kelas eksperimen 72\%, ini dikarenakan pada kelas kontrol tingkat pengetahuannya lebih banyak karena siswa pada kelas kontol hanya menjadi pendengar ketika guru menjelaskan. Sedangkan untuk aspek pemahaman (C2) dan aplikasi (C3) prosentase Keefektifan lebih didominasi ole kelas eksperimen yaitu $87 \%$ dan $93 \%$. Hal tersebut dikarenakan pada kelas eksperimen, siswa dapat belajar lebih efektif, karena mereka dituntut aktif dengan model pembelajaran yang digunakan sehingga tingkat pemahaman merekapun lebih baik.

Dari beberapa penelitian yang sudah dilakukan oleh beberapa peneliti diatas penelitian dengan menggunakan model pembelajaran Make a Match dilakukan pada penelitian ini, peneliti membuat ide untuk memecahkan masalah hasil belajar llmu Pengetahuan Alam SD Negeri Wonosari 03 Kabupaten Batang materi panas dan perpindahannya dengan praktek berpasangan memainkan media kartu soal dan kartu jawaban yang telah disediakan pada masing-masing siswa secara bergantian mengambil kartu dengan di desain ada kartu soal dan ada kartu jawaban dengan sedemikian rupa hingga dapat menarik perhatian siswa sehingga hasil yang di peroleh siswa dapat meningkat. Hal ini terbukti dari hasil penelitian yang dilakukan pada kelas $\mathrm{V}$ yang menunjukkan perbedaan pada hasil belajar sebelum perlakuan nilai pretest menunjukkan rata-rata sebesar 58,8 terdapat 7 siswa yang sudah mencapai KKM dan 23 siswa belum mencapai KKM, sedangkan hasil belajar sesudah perlakuan nilai posttestmenunjukkan rata-rata sebesar 74 terdapat 24 siswa yang sudah mencapai KKM dan 6 siswa yang belum mencapai KKM. Dari hasil nilai pretest dan nilai posttest ini menunjukkan bahwa ada peningkatan terhadap hasil belajar siswa sesudah perlakuan dengan rata-rata 30\%.

Persentase ketuntasan belajar siswa yang menunjukkan pembelajaran tanpa menggunakan model pembelajaran Make a Match sebanyak 7 siswa yang tuntas dengan persentase 23,00\% dan 23 siswa yang belum tuntas dengan persentase $77,00 \%$. Sedangkan setelah diberi perlakuan (posttest) dengan menggunakan model pembelajaran Make a Match yang tuntas ada 24 siswa dengan persentase 80,00\% dan 6 siswa yang belum tuntas dengan persentase $20,00 \%$.

Hasil analisis akhir yang telah dilakukan dengan menggunakan uji t menunjukkan bahwa hasil $\mathrm{t}_{\text {hitung }}>\mathrm{t}_{\text {tabel }}$ yaitu $12,630>2,0639$ maka $\mathrm{H}_{0}$ ditolak dan $\mathrm{H}_{\mathrm{a}}$ diterima, sehingga dapat disimpulkan bahwa model pembelajaran make a Match efektif terhadap hasil belajar siswa pada mata pelajaran llmu Pengetahuan Alam kelas V SD Negeri Wonosari 03 Kabupaten Batang. Penggunaan model pembelajaran Make a Match merupakan alternatif solusi dari pembelajaran yang tidak menggunakan media pembelajaran yang rumit. Model pembelajaran Make a Match mampu mendorong siswa untuk aktif, dan merangsang siswa untuk maju berpendapat dengan teman-teman lain. Proses pembelajaran menggunakan model pembelajaran Make a Match dapat menciptakan suasana belajar yang menyenangkan, aktif, saling bekerja sama dan menumbuhkan minat belajar siswa sehingga hasil belajar siswa juga mengalami peningkatan. 
Berdasarkan analisis hasil belajar siswa dapat disimpulkan bahwa model pembelajaran Make a Match efektif dalam kegiatan pembelajaran dan berhasil meningkatkan hasil belajar siswa pada mata pelajaran llmu Pengetahuan Alam kelas V SD Negeri Wonosari 03 Kabupaten Batang.

\section{Simpulan dan Saran}

Berdasarkan hasil penelitian dan pembahasan, dapat diambil kesimpulan bahwa penggunaan model Make a Match efekif terhadap hasil belajar IPA siswa kelas V SD Negeri Wonosari 03 Kabupaten Batang, hal ini dapat diperkuat dengan : 1) Analisis akhir dengan uji $t$ diperoleh $t_{\text {hitung }}=16,078$. Dari daftar distribusi $t$ dengan $\mathrm{db}=30-1=29$ dan taraf nyata $5 \%$ diperoleh $t_{\text {tabel }}=2,045$. Karena $t_{\text {hitung }}>t_{\text {tabel }}$ maka $\mathrm{H}_{0}$ ditolak dan $\mathrm{H}_{a}$ diterima. 2) Berdasarkan KKM yang ditentukan sekolah yaitu 70, rata-rata hasil belajar siswa yang diberikan perlakuan dengan menerapkan model Make a Match yaitu 74 telah mencapai KKM. Sehingga dapat disimpulkan bahwa model Make a Match efekif terhadap hasil belajar IPA siswa kelas V SD Negeri Wonosari 03 Kabupaten Batang. 3) Berdasarkan aspek kognitif pada siswa mengalami peningkatan. Hal ini terlihat dari nilai rata-rata siswa dari 58,8 menjadi 74. 4) Peningkatan hasil belajar siswa dengan membandingkan nilai pretest dan nlai postest.

Berdasarkan hasil penelitian yang diperoleh, agar proses pembelajaran dapat memberikan hasil yang maksimal maka peneliti menyampaikan saran sebagai berikut: 1) Bagi guru, Saran untuk guru yaitu guru harus lebih kreatif dalam memilih model pembelajaran yang tepat dan disesuaikan dengan materi yang akan diajarkan kepada siswa agar hasil belajar siswa meningkat. Pembelajaran dengan menggunakan model Make a Match berbantu dalam kegiatan belajar mengajar sehingga siswa tidak jenuh dan tidak monoton, dan siswa lebih aktif dalam pembelajaran. Model Make a Match sudah terbukti dapat meningkatkan hasil belajar siswa. 2) Bagi pembaca, Model Make a Match direkomendasikan penulis untuk terus dikembangkan pada mata pelajaran IPA agar siswa tertarik dan aktif. Model dan media pembelajaran lain juga dapat dilakukan untuk menciptakan pembelajaran yang menarik dan menyenangkan. Model Make a Match juga dapat digunakan pada mata pelajaran lainnya dengan menyesuaikan materi pembelajarannya.

\section{Daftar Rujukan}

Agung, A.A. Gede.2014. Buku Ajar Metodologi Penelitian Pendidikan. Edisi 2. Cetakan Pertama. Singaraja: Aditya Media Publising.

BNSP. 2006. Panduan Penyusunan kurikulum Tingkat Satuan Pendidikan Jenjang Pendidikan. Jaelani.2011. Teori Motivasi Belajar. Jakarta: Rajawali Press.

Isjoni. 2010. Cooperative Learning. Bandung : Alfabeta.

Muliyantini, P., \& Parmiti, D. P. 2017. "Penerapan Model Pembelajaran Group Investigation (Gi) Untuk Meningkatkan Hasil Belajar IPA Kelas V". Jurnal Ilmiah Sekolah Dasar, Vol 1. No 2 Tersedia pada. https://ejournal.undiksha.ac.id/index. (Diakses pada tanggal 12 Maret 2018).

Prabandari, Eko. 2007. Ilmu Pengetahuan Alam 5. Jakarta: Bumi Aksara.

Riyanto. 2012. Paradigma Baru Pembelajaran. Jakarta : Kencana Prenada Media Group.

Samatowa, Usman. 2010. Pembelajaran llmu Pengetahuan Alam di Sekolah Dasar. Jakarta: PT Indeks.

Shoimin, Aris. 2014. Model Pembelajaran Inovatif dalam Kurikulum 2013. Yogyakarta: AR-RUZZ MEDIA.

Slameto .2013. Belajar Dan Faktor-faktor Yang Mempengeruhinya. Jakarta: Rinerka Cipta.

Slameto.2010. Belajar Dan Faktor-faktor Yang Mempengeruhinya. Jakarta: Rinerka Cipta.

Sudjana, Nana. 2005. Metode statistika. Bandung : TARSITO.

Sugiyono. 2015. Metode Penelitian Pendidikan (Pendekatan Kuantitatif, KualitatifdanR\&D). Bandung: Alfabeta.

Samatowa, Usman. 2010. Pembelajaran IPA Di Sekolah Dasar. Jakarta: PT Indeks. 
Santayasa, I Wayan. 2005. Belajar dan Pembelajaran. Singaraja: Institusi Keguruan Dan Ilmu Pendidikan.

Sisdiknas. 2006. Undang-Undang Republik Indonesia Nomor 20 Tahun 2003 SISDIKNAS Sistem Pendidikan Nasional. Bandung: Fokusmedia.

Shoimin, Aris. 2014. 68 Model Pembelajaran Inovatif dalam Kurikulum 2013. Jakarta: AR-RUZZ Media.

Susanto, Ahmad. 2013. Teori Belajar dan Pembelajaran di Sekolah Dasar. Jakarta: Kencana Prenada Media Group. JEAR, Vol. 2, No. 3, Tahun 2018, pp. 240-248 248 JEAR. P-ISSN: 2580-4790 E-ISSN: 2549-3272

Suyatno. 2009. Menjelajah Pembelajaran Inovatif. Sidoarjo:Masmedia Buana Pustaka.

Trianto. 2009. Mendesain Model Pembelajaran Inovatif-Progresif. Jakarta: Kencana Prenada Media Group.

Yesiana, P. F. 2016." Pengaruh Model Pembelajaran Make A Match Terhadap Hasil Belajar IPA Siswa Kelas V SD Negeri Gugus IV Kabupaten Buleleng Tahun Pelajaran 2016/2017". Mimbar Pgsd. Volume 6, Nomor 3. Tersedia pada ttps://ejournal 